\title{
SYNTHESIS AND PROPERTIES OF MERCURY SELEN IDE FILMS DEPOSITED BY USING POTTASIUM IODIDE AS COMPLEXING AGENT
}

\author{
Martyn Sozanskyi, ${ }^{1}$, Vitalii Stadnik ${ }^{1}$, Ruslana Chaykivska ${ }^{1}$, Ruslana Guminilovych ${ }^{1}$, \\ Pavlo Shapoval $^{1}$, losyp Yatchyshyn ${ }^{1}$
}

https://doi.org/10.23939/chcht11.04.445

\begin{abstract}
Mercury selenide (HgSe) films were obtained on glass substrates via the chemical deposition method. The aqueous solutions of mercurium(II) nitrate, potassium iodide and sodium selenosulfate were used. Film samples obtained at two temperatures of synthesis were analyzed by X-ray and structural analysis. The effect of the deposition duration on the optical and morphological properties of $\mathrm{HgSe}$ films was investigated. The deposition mechanism was discussed.
\end{abstract}

Keywords: mercury selenide, thin films, chemical bath deposition, optical properties, morphology analysis, reaction mechanism.

\section{Introduction}

Synthesis and investigation of semiconductor materials based on $\mathrm{A}^{\mathrm{II}} \mathrm{B}^{\mathrm{VI}}$ thin films (chalcogenides $\mathrm{Zn}, \mathrm{Cd}$ and $\mathrm{Hg}$ ) have gained considerable attention due to their unique properties. Mercury chalcogenides are technologically attractive materials that can be used in IR detectors, ultrasonic transducers, catalysts, electrostatic reflective materials and solar cells [1, 2]. Limited information about the features of synthesis and the properties of mercury chalcogenides film materials is explained by the difficulties arising during their production. First of all, this is related to impossibility to use the typical complexing reagents that have been successfully used for the synthesis of cadmium and zinc chalcogenide films with a given set of properties. Therefore, the development of a simple and reproducible technique for the synthesis of mercury selenide films is an actual task.

Technologically convenient way of films obtaining is the chemical bath deposition [3]. Previously, the

\footnotetext{
${ }^{1}$ Lviv Polytechnic National University,

12 Bandera St., 79013 Lviv, Ukraine

* martyn.a.sozanskyi@lpnu.ua

○ Sozanskyi M, Stadnik V., Chaykivska R., Guminilovych R., Shapoval P., Yatchyshyn I., 2017
}

chalcogenide films of zinc $[4,5]$ and cadmium $[6,7]$ were successfully obtained by this method. It is based on interaction reactions between the metal salt, complexing agent and chalcogenizer in an aqueous solution. In the case of mercury selenide ( $\mathrm{HgSe}$ ) films it is convenient to use potassium iodide for complexation, since it forms a fairly stable complex with mercury. The most available Se-chalcogenizer is sodium selenosulfate. The formation of selenides is a combination of chemical reactions, the mechanism of which can depend on the synthesis conditions.

The aim of this work was to carry out complex studies: experimental investigation of the composition, structure, optics and morphology of the synthesized $\mathrm{HgSe}$ semiconductor films depending on the synthesis duration at different temperatures. An analysis of the obtained experimental results will allow to relate $\mathrm{HgSe}$ deposition conditions with the properties of the obtained semiconductor films and to investigate the mechanism of their synthesis. This is an actual task of thin-film technologies, the solution of which will allow to control the process of chemical deposition of mercury selenide films.

\section{Experimental}

\subsection{M aterials}

Chemical deposition of $\mathrm{HgSe}$ films was carried out on preliminarily cleaned glass substrates of $18 \times 18 \mathrm{~mm}$ size. A working solution was prepared by step-by-step adding of freshly prepared aqueous solutions of the mercury salt, a complex reaction agent, a chalcogenizing reagent and distilled water.

The composition of the working solution was: $0.01 \mathrm{M}$ mercury(II) nitrate $\left(\mathrm{Hg}\left(\mathrm{NO}_{3}\right)_{2}\right), 0.04 \mathrm{M}$ potassium iodide (KI) as a complex-forming reagent for $\mathrm{Hg}^{2+}$ and $0.01 \mathrm{M}$ sodium selenosulfate $\left(\mathrm{Na}_{2} \mathrm{SeSO}_{3}\right)$ as a source of $\mathrm{Se}^{2-}$. Such composition corresponds to the 1:4:1 molar ratio between the reagents. The $\mathrm{pH}$ of the working solution was $\sim 9.5$. The deposition was made in a glass 
bath for 2-10 min at the temperature of $363 \mathrm{~K}$ and $24-$ $48 \mathrm{~h}$ at the temperature of $293 \mathrm{~K}$. After this, the substrates were removed, washed with distilled water and dried in the air.

The film samples, synthesized at 363 and $293 \mathrm{~K}$, had dark-brown and dark-orange colors, respectively. Their adhesion to the glass substrate was weak. The films were easily removed if we applied small mechanical forces.

\subsection{Analysis}

Experimental arrays of intensities and angles of reflection of the test samples were obtained on DRON-3.0 $\mathrm{X}$-ray diffractometer $\left(\mathrm{CuK} \alpha^{-}\right.$radiation). Preliminary processing of the experimental diffraction arrays in order to identify the phases was carried out using PowderCell [8]. Calculation of the cell parameters were done by using the FullProf software package [9].

The films optical transmission spectra were recorded on Xion 500 "Dr. Lange" spectrophotometer in the 340-900 nm wavelength range. The accuracy of the optical transmission detection was $\pm 0.5 \%$.

Investigation of the films surface morphology was performed by using REMMA-102-02 raster scanning electron microscope (SEM) with a microanalysis system.

\section{Results and Discussion}

The phase composition was set by X-ray-phase analysis of the synthesized samples (Fig. 1).

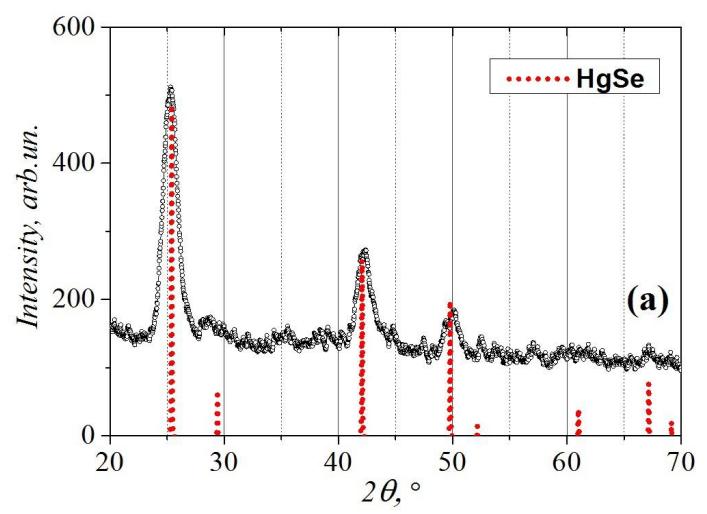

A single-phase composition of the $\mathrm{HgSe}$ film sample was established at $363 \mathrm{~K}$ and two-phase composition - at $293 \mathrm{~K}$. Such result may indicate different synthesis mechanisms at different temperatures. We identified $\mathrm{HgSe}$ in the cubic modification (structural type $\mathrm{ZnS}$, sphalerite) and the ternary compound of mercuryiodide-selenide $\left(\mathrm{Hg}_{3} \mathrm{I}_{2} \mathrm{Se}_{2}\right)$ in the monoclinic modification (structure type $\mathrm{Hg}_{3} \mathrm{~B}_{12} \mathrm{~S}_{2}$ ). Crystallographic characteristics of the obtained compounds are given in Table 1 .

The optical transmission of films (Fig. 2a, b) decreases with the increase of synthesis duration. For single-phase $\mathrm{HgSe}$ films a light transmission jump is visible in $\sim 400 \mathrm{~nm}$ region of wavelengths. For two-phase films, the nature of the change in transmission is somewhat different. Their spectra show two inflections in the regions of wavelengths: $\sim 400$ and $\sim 500 \mathrm{~nm}$, which correspond to mercury selenide and mercury-iodideselenide, respectively.

Absorption spectra dependences in $(\alpha \cdot h v)^{2}=f(h v)$ coordinates (Fig. 2c,d) show the presence of fundamental optical absorption edge. The optical band gap (defined as the intersection point of the tangent to linear section of the dependence $(\alpha \cdot h v)^{2}=f(h v)$ and the $x$-axis) of HgSe films, obtained at $363 \mathrm{~K}$ and the synthesis duration of $2-10 \mathrm{~min}$ is $2.90-2.05 \mathrm{eV}$, respectively. In the case of films, synthesized at $293 \mathrm{~K}$, two bending transitions are observed, corresponding to the two-phase composition of the samples. They are most pronounced at the duration of $48 \mathrm{~h}$. The optical band gap values are localized in the regions of 2.65-2.61 eV for $\mathrm{HgSe}$ and $2.29-2.22 \mathrm{eV}$ for $\mathrm{Hg}_{3} \mathrm{I}_{2} \mathrm{Se}_{2}$ at the synthesis duration of 24-48 h, respectively.

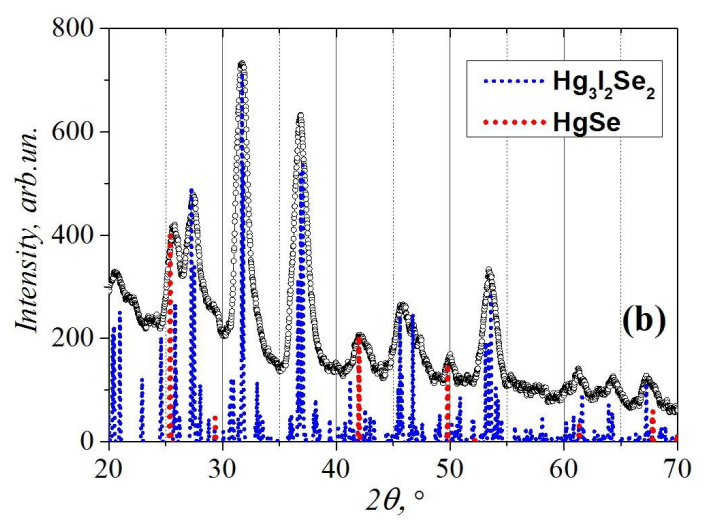

Fig. 1. Experimental profiles of diffractograms of HgSe films, obtained at synthesis temperatures of $363 \mathrm{~K}$ (a) and $293 \mathrm{~K}$ (b)

Table 1

Crystallographic characteristics of compounds in the films obtained at different synthesis temperatures

\begin{tabular}{|c|c|c|c|c|c|c|c|c|}
\hline \multirow{2}{*}{ Synthesis temperature } & \multirow{2}{*}{ Phases } & \multirow{2}{*}{ Structure type } & \multirow{2}{*}{ Pearson's symbol } & \multirow{2}{*}{ Space group } & \multicolumn{4}{|c|}{ Cell parameters } \\
\hline & & & & & $a, \mathrm{~nm}$ & $b, \mathrm{~nm}$ & $c, \mathrm{~nm}$ & $\beta,^{\circ}$ \\
\hline $363 \mathrm{~K}$ & $\mathrm{HgSe}$ & $\mathrm{ZnS}$ & $c F 8$ & $F-43 m$ & $0.60550(11)$ & - & - & - \\
\hline \multirow{2}{*}{$293 \mathrm{~K}$} & $\mathrm{Hg}_{3} \mathrm{I}_{2} \mathrm{Se}_{2}$ & $\mathrm{Hg}_{3} \mathrm{~S}_{2} \mathrm{Br}_{2}$ & $m S 56$ & $C 12 / m 1$ & $1.9374(4)$ & $0.9654(3)$ & $1.0933(4)$ & 116.67(2) \\
\hline & $\mathrm{HgSe}$ & $\mathrm{ZnS}$ & $c F 8$ & $F-43 m$ & $0.60523(16)$ & - & - & - \\
\hline
\end{tabular}



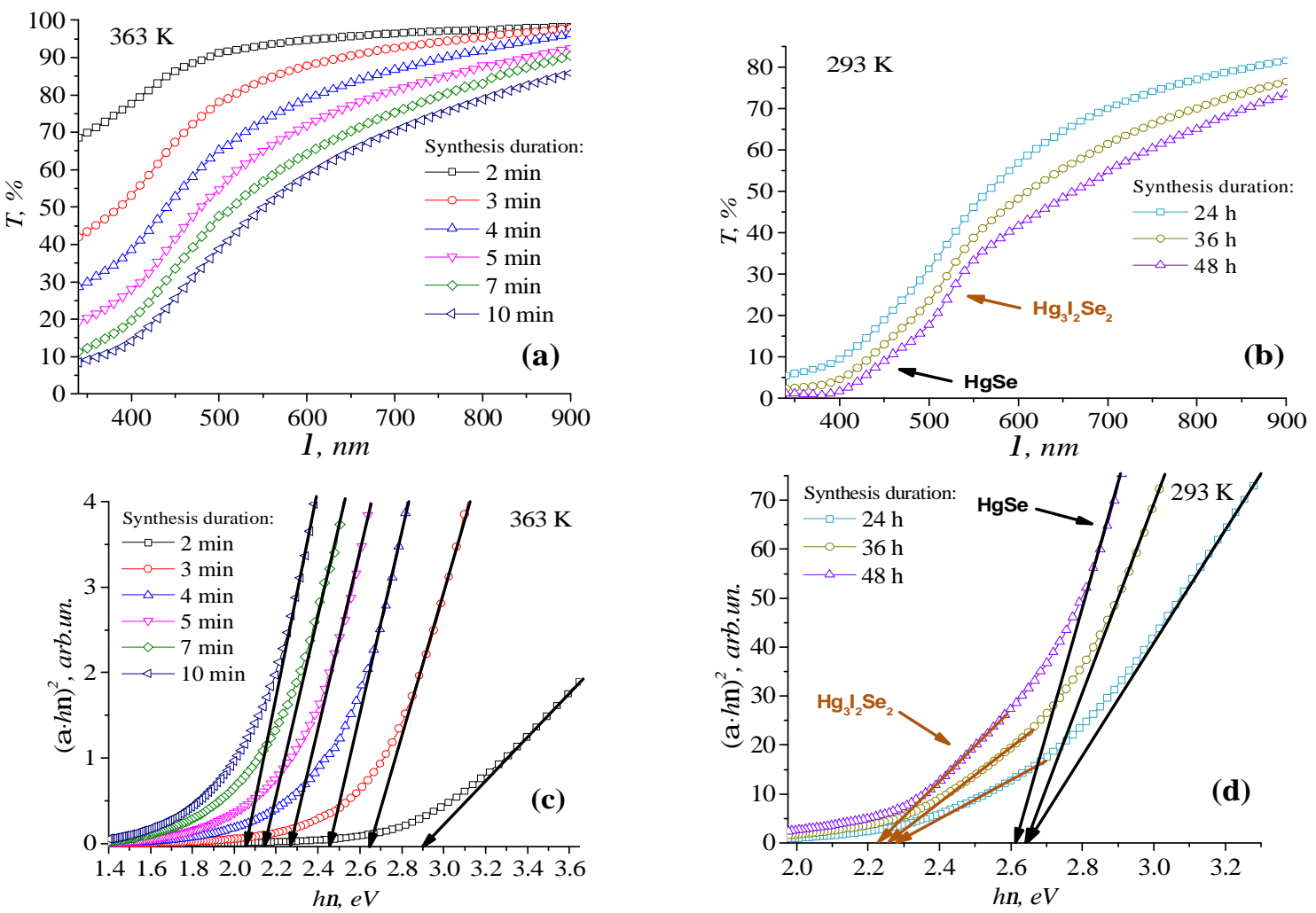

Fig. 2. Spectral dependences of optical transmission $(T, \%)(a, b)$ and their respective dependences $(\alpha \cdot h v)^{2}=f(h v)(\mathrm{c}, \mathrm{d})$, where $\alpha$-optical absorption coefficient of the films, obtained at different temperatures and synthesis duration

Table 2

The surface morphology and atomic composition of the films depending on synthesis duration

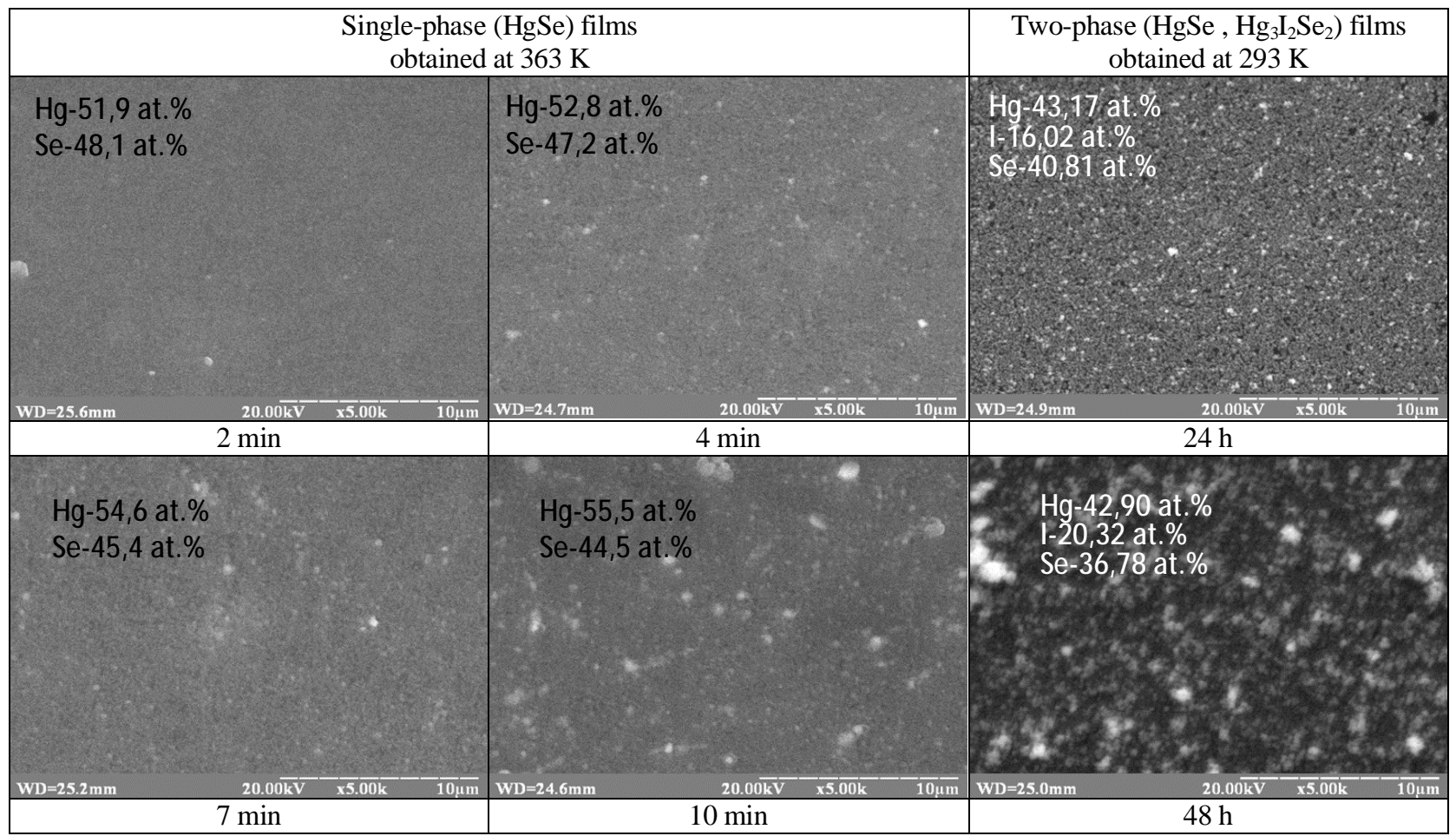


Spectroscopic studies of the films surface morphology (Table 2) show that films deposited at different temperatures and synthesis duration, are completely covering the substrate and are solid and homogeneous along the whole area. The surface morphology of films, synthesized at $293 \mathrm{~K}$ is somewhat different than those synthesized at $363 \mathrm{~K}$. Inclusions of phase particles $\left(\mathrm{Hg}_{3} \mathrm{I}_{2} \mathrm{Se}_{2}\right)$ between $\mathrm{HgSe}$ phase are observed on them, indicating the formation of a ternary compound through the entire reaction.

According to the results of microanalysis, the single-phase $\mathrm{HgSe}$ films have a practically stoichiometric composition with a slight excess of mercury atoms. For the two-phase films the iodine was found in the film structure. This fact is in agreement with the data of previous studies.

On the basis of the experimental data, we can assert that the temperature determines the course of $\mathrm{HgSe}$ films synthesis reaction mechanism. At $363 \mathrm{~K}$ the formation and growth of the film begins with the formation of mercury complexes with iodide. Complex metal particles are capable to react with selenosulfate [10]. Schematically, this process can be written as follows:

$$
\begin{gathered}
\mathrm{Hg}^{2+}+4 \mathrm{I}^{-} \longrightarrow\left[\mathrm{HgI}_{4}\right]^{2-} \\
{\left[\mathrm{HgI}_{4}\right]^{2-}+\mathrm{SeSO}_{3}^{2-}+2 \mathrm{OH}^{-} \longrightarrow \mathrm{HgSe}^{-}+\mathrm{SO}_{4}^{2-}+4 \mathrm{I}^{-}+\mathrm{H}_{2} \mathrm{O}}
\end{gathered}
$$

At $293 \mathrm{~K}$ the above given reactions will also take place. In this case mercury selenide will stay longer in suspension form before depositing as the film on the substrate and in the form of corresponding precipitate. The result is that a significant part of $\mathrm{HgSe}$ interacts with $\left[\mathrm{HgI}_{4}\right]^{2-}$ forming $\mathrm{Hg}_{3} \mathrm{I}_{2} \mathrm{Se}_{2}$ ternary compound. Schematically, this process can be written as follows:

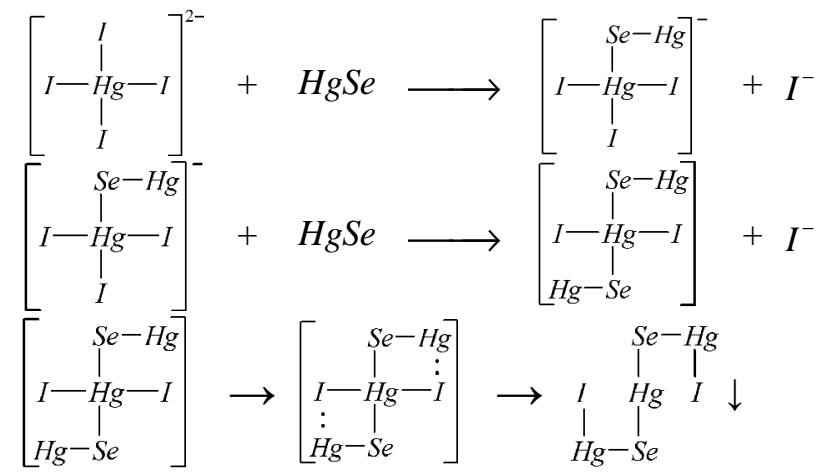

The arrangement of atoms in the final product of $\mathrm{Hg}_{3} \mathrm{I}_{2} \mathrm{Se}_{2}$ corresponds to its crystal structure according to $\mathrm{X}$-ray diffraction analysis.

\section{Conclusions}

In this work, we comprehensively considered the problem of mercury selenide films synthesis with the aim of developing common rules and approaches for controlling the process of their hydrochemical synthesis.
The influence of synthesis duration and temperature on the properties of $\mathrm{HgSe}$ films has been proved. From the practical standpoint, it is expedient to use higher temperature $(363 \mathrm{~K})$ and short duration $(2-10 \mathrm{~min})$ for the synthesis of $\mathrm{HgSe}$ films from aqueous $\mathrm{KI}$ solutions because these films are single-phase, solid and homogeneous. The use of room temperature is pointless due to the uncontrolled formation of a significant amount of byproduct $\left(\mathrm{Hg}_{3} \mathrm{I}_{2} \mathrm{Se}_{2}\right)$, as a result of different mechanism of coating growth.

\section{Acknowledgments}

This research is conducted under the project "Thin Film Semiconductor Materials for Photo Sensitive Solar Cells” (State Registration № 0117U004455).

\section{References}

[1] Marimuthu G., Ramalingam K., Rizzoli C. et al.: J. Nanopart. Res., 2012, 14, 710. https://doi.org/10.1007/s1 1051-011-0710-7 [2] Salavati-Niasari M., Esmaeili-Zare M., Sobhani A.: Micro Nano Lett., 2012, 12, 1300. https://doi.org/10.1049/mnl.2012.0709

[3] Bansode S., Kapadnis R., Wagh V. et al.: Chem. Chem. Technol., 2014, 8, 441.

[4] Shapoval P., Sozanskyi M., Yatchyshyn I. et al.: Chem. Chem. Technol., 2016, 10, 317. https://doi.org/10.23939/chcht10.03.317 [5] Sozanskyi M., Shapoval P., Chaykivska R., et al.: Visnyk Lviv. Polytech. Nats. Univ., 2016, 841, 36.

[6] Shapoval P., Guminilovych R. and Yatchyshyn I.: Chem. Chem. Technol., 2013, 7, 345.

[7] Shapoval P., Guminilovych R. Yatchyshyn I. et al.: Chem. Chem. Technol., 2015, 9, 287.

https://doi.org/10.23939/chcht09.03.287

[8] Kraus W., Nolze G.: PowderCell for Windows (version 2.4). Federal Institute for Materials Research and Testing, Berlin 2000. [9] Rodriguez-Carvajal J.: FULLPROF: Satellite Meeting on powder Diffraction of the XV Congress of the IUCr, Toulouse, France, 1990, 127.

[10] Singh S., Rath M., and Sarkar S. K.: J. Phys. Chem.

A, 2011, 115 , 13251. https://doi.org/10.1021/jp206028x

Received: March 23, 2017 / Revised: April 04, 2017 / Accepted: August 14, 2017

\section{СИНТЕЗ І ВЛАСТИВОСТІ ПЛІВОК МЕРКУРІЙ СЕЛЕНІДУ, ОТРИМАНИХ З ВИКОРИСТАННЯМ КАЛІЙ ЙОДИДУ ЯК КОМПЛЕКСОУТВОРЮЮЧОГО РЕАГЕНТА}

Анотація. Методом хімічного осадження ванн отримано плівки меркурій селеніду (HgSe) на скляних підкладках з використанням водних розчинів меркурій(II) нітрату, калій йодиду і натрій селеносульфату. Проведено рентгенофазовий та структурний аналіз отриманих зразків плівок за двох різних температур синтезу. Досліджено вилив тривалості осадження на оптичні та морфологічні властивості плівок $\mathrm{HgSe}$. Обговорено механізм осадження.

Ключові слова: меркурій селенід, тонкі плівки, хімічне осадження з ванн, оптичні властивості, аналіз морфології, механізм реакиії. 